\begin{tabular}{lllll} 
ZAPISKI HISTORYCZNE & $-\underset{\text { Zeszyt } 4}{\text { TOM }}$ & LXXX & - ROK 2015 \\
\hline
\end{tabular}

http://dx.doi.org/10.15762/ZH.2015.55

MACIEJ DORNA

(Adam Mickiewicz University in Poznań)

\title{
ABOUT THE DATE WHEN THE FOUNDATION PRIVILEGE WAS GRANTED TO CHEŁMNO AND TORUŃ
}

Key words: diplomatics, the Chełmno privilege, Kulmer Handfeste, the Teutonic Order, Chełmno Land

"Acta sunt hec in Culmine anno incarnacionis dominice millesimo ducentesimo tricesimo tercio, quinto Kalendas Januarii" - despite the fact that the authors of the foundation privilege for Chełmno and Torun used this formula to clearly define the date when the document was issued, it lost its original clarity since, over time, the style of defining the beginning of a year which was used to date the document had been forgotten ${ }^{1}$. As a result, historiographers have not managed to generate one consistent point of view in relation to the issue of the Chelmno foundation privilege which, as we know, may be dated to 28 December 1232 (if the Nativity method was used), or to 28 December 1233 (if the writers used the Circumcision style or the Annunciation style).

Among scholars, the opinion has invariably prevailed that the latter date is correct $^{2}$. However, the recent attempt to revise this point of view by Marc Löwener has

\footnotetext{
${ }^{1}$ Cited after Preussisches Urkundenbuch. Politische Abtheilung, Bd. 1, hrsg. v. Rudolf PhilipPI, Königsberg 1882 (further: PrUB I/1), no. 105; see also: Guido KIsCH, Die Kulmer Handfeste, Sigmaringen 1978 (the first edition 1931), p. 110 ff; Karola Ciesielska, Przywilej chetmiński 1233-1251, Torun 1983, p. 15 ff; eadem, Przywileje lokacyjne Torunia, Toruń 2008, p. 25 ff; Krystyna ZIELIŃska-Melkowska, Przywilej chetmiński 1233 i 1251, Toruń 1986, p. 34 ff.

${ }^{2}$ Let us provide here only those authors whose speculations about the dating of the Chelmno privilege were the result of their reasoning Max ToEPPEN, Geschichte der preussischen Historiographie von P. v. Dusburg bis auf K. Schütz, Berlin 1853, p. 279 f; Chronicon terrae Prussiae von Peter von Dusburg, hrsg. v. Max Toeppen, [in:] Scriptores rerum Prussicarum, Bd. 1, hrsg. v. Theodor Hirsch, Max Töppen, Ernst StrehlKe, Leipzig 1861, p. 56, fn. 3, and p. 57, fn. 3 - the publisher's remarks; R. Philippi, PrUB I/1, no. 105, p. 77, fn. 1 - the publisher's remarks; Willy CoHn, Hat Hermann von Salza das Deutschordensland betreten?, Historische Vierteljahresschrift, Jg. 25: 1930, p. 390 ff; Erich MaschKe, [rev. W. Cohn, Hermann von Salza, Breslau 1930], Altpreussische Forschungen, Jg. 8: 1931, p. 147 ff; G. Kisch, op.cit., p. 4 f, fn. 2; Tomasz JAsı́́ski, Pierwsze lokacje miast nad Wista. 750 lat Torunia i Chetmna, Toruń 1980, p. 39; K. Zielińska-Melkowska, op.cit., p. 23, fn. 2; Marian Dygo, Studia nad poczatkami władztwa Zakonu Niemieckiego w Prusach, Warszawa 1992, p. 87, fn. 326; Dariusz Sikorski, Przywilej kruszwicki. Studium z wczesnych dziejów zakonu niemieckiego w Prusach, Warszawa 2001, p. 82 f, fn. 89.
} 
generated a debate concerning the actual date of granting the foundation privilege to Chełmno and Torun' ${ }^{3}$. The discussion has returned to its starting point, and in this situation the best solution seems to be the revision of all the circumstances important for the dating of the Chełmno privilege.

Let us commence with Marc Löwener's proposals, which have already been accepted in historiography ${ }^{4}$. In his attempt to establish the correct date of the Chełmno privilege, the German author put special emphasis on the analysis of the itineraries taken by the people mentioned in the text of the document. First of all, he was interested in the co-drafter of the privilege, Grand Master Hermann von Salza and three other Teutonic witnesses - the burgrave of Magdeburg Burchard von Querfurt, Johann von Pach and Bernhard von Kamenz.

In the case of Hermann von Salza, Marc Löwener tried to prove the possibility that the grand master of the Teutonic Order did not stay all the time in the Mediterranean region in the years $1232-1234$, as believed so far. On the contrary, at the turn of 1232 and 1233 he visited Chełmno Land, where on 28 December 1232 he took part in granting the foundation privilege to Torun and Chełmno. For the German scholar, the argument supporting this hypothesis is the witness list of the document issued by Casimir I of Kuyavia for the Teutonic Order, which was dated on 6 January 1233. According to M. Löwener, the document lists not only the provincial master of Prussia Hermann Balk, but also Hermann von Salza himself ${ }^{5}$. Besides, M. Löwener underlined the lack of clear evidence for Hermann von Salza's activity in the Holy Land in the first half of 1233. Moreover, Löwener indicated the information included in the letter of the emperor Frederic II to Pope Gregory IX of 12 July 1233, according to which Hermann von Salza was at that time coming back to the emperor's court from a journey, as the German author identifies, from Prussia ${ }^{6}$.

\footnotetext{
${ }^{3}$ Marc Löwener, Die Einrichtung von Verwaltungsstrukturen in Preußen durch den Deutschen Orden bis zur Mitte des 13. Jahrhunderts, Wiesbaden 1998, p. 47 ff; idem, Poczatki Zakonu Niemieckiego w Prusach do połowy XIII wieku, Zapiski Historyczne (further: ZH), vol. 65: 2000, no. 1, p. 14 ff.

${ }^{4}$ See: Sławomir Jóźwiak, Specjalni wysłannicy wielkich mistrzów do Prus i Inflant. Przyczynek do funkcjonowania centralnych i terytorialnych organów władzy zakonu krzyżackiego w połowie XIII wie$k u$, Roczniki Humanistyczne, vol. 48: 2000, no. 2, p. 195; idem, [rev. M. Löwener, Die Einrichtung], Komunikaty Mazursko-Warmińskie, 2000, no. 1, p. 113 f; Simon Helms, Luther von Braunschweig. Der Deutsche Orden in Preußen zwischen Krise und Stabilisierung und das Wirken eines Fürsten in der ersten Hälfte des 14. Jahrhunderts (Quellen und Studien zur Geschichte des Deutschen Ordens, Bd. 67), Marburg 2009, p. 71; see also: Państwo zakonu krzyżackiego w Prusach. Podziały administracyjne i kościelne, ed. Zenon Hubert NowaK, Roman Czaja, Toruń 2000, p. 49; and also: Klaus MiliTZER, Anmerkungen zu einem neuen Werk über die Anfänge der Verwaltung in Preußen durch den Deutschen Orden, Preussenland, Jg. 38: 2000, Nr. 1, p. 3 f, where the author does not support expressis verbis $\mathrm{M}$. Löwener's view, but still he regards his arguments as significant.

${ }^{5}$ M. Löwener, Die Einrichtung, p. 50 ff; idem, Początki, p. 15.

${ }^{6}$ Idem, Die Einrichtung, p. 52 ff; idem, Poczatki, p. 15; letter of Frederick II, 12 July 1233 see: Monumenta Germaniae Historica. Legum sectio IV. Constitutiones et acta publica imperatorum et regum, vol. 2, ed. Ludwig Weiland, Hannover 1896, no. 179.
} 
On the other hand, the analysis of the itineraries of Burchard von Querfurt, Johann von Pach and Bernhard von Kamenz served Löwener as the basis to formulate the conclusion that the three Teutonic crusaders could not have stayed in Chełmno Land in December 1233. The German author supported his thesis with two assumptions. Firstly, all the three Teutonic crusaders went for a crusade to Prussia and returned together. Secondly, they spent one year crusading, the evidence for which is the record of Peter of Dusburg confirming that the crusade in which Burchard von Querfurt participated lasted one year. Consequently, pointing out the presence of Johann von Pach and Bernhard von Kamenz in Germany on 21 August 1233 and indicating the presence of Burchard von Querfurt in Germany at the beginning of July 1234, Löwener concluded that the three knights could not have stayed in Chełmno on 28 December 1233 if the interval between their stay in Germany before December and after December 1233 was shorter than a year?

At the same time, being aware of the discrepancy between his conclusions and the observation made by Erich Maschke (according to the latter, one of the witnesses - the provisor of Quidin Ludwig - could not have appeared in sight until 1233 when, as Peter of Dusburg writes in his chronicle, Quidin-Marienwerder was constructed), Marc Löwener tried to undermine the credibility of Peter's chronicle in this respect, putting forward a suggestion that the foundation date of Quidin-Marienwerder given by Peter of Dusburg may have resulted from his erroneous reference to the information included in some Prussian annals that the town ("civitas") of Marienwerder was established in 1233 to the construction of Marienwerder castle ("castrum"), which might have taken place as early as $1232^{8}$.

Unfortunately, the attempt to prove the validity of the Chelmno privilege being dated to 28 December 1232 cannot be regarded as a research breakthrough since the argumentations employed by Löwener reveal fundamental weaknesses 9 .

Thus, there are no grounds that the document of 6 January 1233 should be treated as proof of Hermann von Salza's presence in Prussia, because there are more arguments which support the thesis that brother Hermann should be identified with the provincial master Hermann Balk ${ }^{10}$. Moreover, in the light of the source material, the problem of Hermann von Salza's itinerary in the first half of 1233 looks different from what Marc Löwener presented. What plays the key role here is the letter written by Pope Gregory IX on 22 March 1234, in which the pope confirmed the settlement between the barons of the Kingdom of Jerusalem and the municipal commune of Acre with Emperor Frederic II. The mediator of

\footnotetext{
${ }^{7}$ M. Löwener, Die Einrichtung, p. 59 ff; idem, Początki, p. 16 f.

${ }^{8}$ Idem, Die Einrichtung; p. 67; idem, Poczatki, p. 17.

${ }^{9}$ To be precise, let us underline that the German scholar avoided any kind of positiveness in his speculations; his research was to invite to a discussion rather than to resolve the question of dating the Chełmno privilege; see: idem, Die Einrichtung, p. 67; idem, Początki, p. 17.

${ }^{10}$ See: Maciej Dorna, Bracia zakonu krzyżackiego w Prusach w latach 1228-1309, Poznań 2004, p. 232 ff; idem, Die Brüder des Deutschen Ordens in Preußen 1228-1309. Eine prosopographische Studie, Wien-Köln-Weimar 2012, p. 253; see also: K. MilitZer, op.cit., p. 2 f.
} 
the settlement was the pope's legate, the patriarch of Antiochia Albert, along with Hermann von Salza ${ }^{11}$. Marc Löwener considered the letter to be the evidence for his thesis that in the months preceding the act of writing the letter, Hermann von Salza stayed in the Holy Land, where he could not have travelled from Italy until September $1233^{12}$.

This interpretation of the pope's confirmation raises serious doubts, for the letter was not written directly after signing the settlement. The pope wrote that the conditions of the settlement had been observed "hitherto" ("hactenus") and that in the meantime they were to be confirmed by the emperor ${ }^{13}$. In this situation, dating the settlement to the beginning of 1234, as Löwener suggests, does not seem correct; the signing of the settlement and Hermann von Salza's sojourn in the Holy Land should be dated to the first half of 1233 when, as the sources prove, Hermann von Salza was away from Frederic II's court and the papal curia.

What seems to weigh against the previously mentioned dating of Hermann von Salza's mission is the account of Philip de Novare, according to which in the first half of 1233 a bishop of Sidon, whose name was unknown, was to run the negotiations on behalf of Emperor Frederic II in the Holy Land. However, the thorough analysis of this source, which Marc Löwener used in his argumentation, does not allow us to exclude the possibility of dating the mission of Hermann von Salza and the patriarch of Antiochia to the same semester ${ }^{14}$. The French chronicler did not provide any information allowing us to date the mission of the bishop of Sidon precisely; the only chronological reference point for the events described by him is the information that John of Ibelin, who took part in the negotiations with the bishop of Sidon, returned to Cyprus, where the siege of Kyrenia continued. According to historians, the siege terminated in July $1233^{15}$. It must be stressed here that Phillip de Novare's account does not lead us to conclude that the return of John of Ibelin to Cyprus was to take place immediately before Kyrenia had surrendered. That is why, there is no reason why we should date the mission of the bishop of Sidon to the

${ }^{11}$ Monumenta Germaniae Historica. Epistolae saeculi XIII e regestis pontificum romanorum, ed. Georg Heinrich Pertz, Carl Rodenberg, vol. 1, Berlin 1883 (further: MGH. Epp. saec. XIII), no. 578.

${ }^{12}$ M. Löwener, Die Einrichtung, p. 57 f; in a similar way the document was interpreted by Helmuth KLUger, Hochmeister Hermann von Salza und Kaiser Friedrich II. Ein Beitrag zur Frühgeschichte des Deutschen Ordens (Quellen und Studien zur Geschichte des Deutschen Ordens, Bd. 37), Marburg 1987, p. $177 \mathrm{ff}$; in contrast to Löwener Kluger thought that Herman von Salza stayed in the Holy Land from the end of 1232.

${ }^{13}$ See: MGH. Epp. saec. XIII, no. 578: “[...] compositionem [...] quam idem imperator postmodum per suas litteras confirmavit, ratam habentes et firmam, eam, sicut rite sine pravitate provide facta est et ab utraque parte sponte recepta et hactenus pacifice observata [...] confirmamus [...]"; to be exact, let us note that M. Löwener underlined the information himself, but he didn't see in it any obstacle for his thesis concerning the chronology of Hermann von Salza's stay in the Holy Land; see: idem, Die Einrichtung, p. 57 f.

${ }^{14}$ See: idem, Die Einrichtung, p. 55 f; Philippe de Novare, Mémoires 1218-1243, ed. Charles Kohler, Paris 1913 (further: Philippe de Novare, Mémoires), p. 84 ff.

${ }^{15}$ Philippe de Novare, Mémoires, p. 88. 
period directly preceding this event, and not in the earlier months in $1233^{16}$. In this situation, there is no reason to exclude the possibility that after the unsuccessful mission of the bishop of Sidon, the grand master of the Teutonic Order and the patriarch of Antiochia made another attempt to moderate the anti-imperial sentiments in the Kingdom of Jerusalem before the middle of the year 1233 .

What prejudges the case is, as it seems, the chronology of the legate's mission of the patriarch Albert, who accompanied Hermann von Salza in the negotiations leading to the conclusion of the agreement mentioned in the pope's letter of 22 March $1234^{17}$. The legate's mandate of Albert, who had been appointed a legate a year earlier, was restricted to the territory of the patriarchate of Antiochia in the summer of 1233 , which prompts us to date the conclusion of the discussed treaty not later than the middle of $1233^{18}$.

In this situation it may be assumed that the return journey of the grand master to the court of Frederic II in Syracuse, mentioned in the letter of 12 July 1233, was a journey from the Holy Land, and not from Prussia, which, in turn, allows us to question the legitimacy of treating this source information as circumstantial evidence indicating Hermann von Salza's stay in Chełmno Land in December 1232.

Likewise, Löwener's argument stemming from the itineraries of Burchard von Querfurt, Johann von Pach and Bernhard von Kamenz does not allow us to date the Chełmno privilege to December 1232. In fact, it leads to a conclusion that the year spent on the crusade by Burchard von Querfurt and the remaining two Teutonic crusaders could not include the 28th of December 1233 since the Teutonic crusaders appear before this day and after this day in Germany for a period of time shorter than twelve months.

Löwener's argument would hold true only if the assumption that the Chełmno privilege was issued on 28 December 1232 did not exclude a one-year crusade of the Teutonic crusaders. Moreover, Johann von Pach both before and after December 1232 is found in Germany within a ten-month-long period - on 21 October 1232 and 21 July $1233^{19}$.

In view of the aforementioned considerations, it should be stated that Löwener did not manage to prove convincingly the hypothesis that the date of issuing the foundation privilege for Chełmno and Toruń was 28 December 1232. At the same

${ }^{16}$ Despite this H. Kluger, op.cit., p. 183, dated the ending of the mission in May-June 1233; Ch. Kohler, the editor of "Memoirs" of Philippe de Novare dated the mission in the spring of 1233; see: Philippe de Novare, Mémoires, p. 137.

${ }^{17}$ See: MGH. Epp. saec. XIII, no. 578: “[...] mediantibus venerabili fratre nostro . . Antiocheno patriarcha, legato sedis apostolice, ac dilecto filio . . magistro hospitalis sancte Marie Theutonicorum Ierosolimitane [...]".

${ }^{18}$ Ibid., no. 534; about the beginnings of Albert's legacy: ibid., no. 476-479; comp. H. KLUGER, op.cit., p. 177.

${ }^{19}$ Codex diplomaticus Saxoniae regiae, Hauptteil 1, Bd. 3: Urkunden der Markgrafen von Meissen und Landgrafen von Thüringen 1196-1234, hrsg. v. Otto Posse, Leipzig 1898, no. 475; Codex diplomaticus Saxoniae regiae, Hauptteil 2, Bd. 4: Urkundenbuch der Stadt Meissen und ihrer Klöster, hrsg. v. Ernst Gotthelf Gersdorf, Leipzig 1873, no. 399. 
time, it should be noted that some time ago, Max Perlbach also supported this date. He thought that the allusion to Prussian raids in Chelmno Land, mentioned in the text of the document, corresponded better the situation at the end of 1232 than the period after the defeat of Prussians in the battle of Sirgune which, according to this author, took place in $1233^{20}$. What is more, according to Perlbach, the record about the Chełmno law - "Utentur autem supradicti iure Culminensi" - was included in the patronage document of the duke Vladislaus Odonic issued in 1233 for German settlers in the village of Panigródz belonging to the Łekno monastery ${ }^{21}$.

Those arguments do not provide any grounds for acknowledging December 1232 to be a more probable date of issuing the Chełmno privilege than December 1233. As far as the first argument is concerned, it is enough to indicate a lack of evidence for the great crusade of the Polish dukes and the battle of Sirgune taking place as early as 1233. Suffice it to say, the account about the crusade found in the chronicle of Peter of Dusburg fails to bear the year of its occurrence ${ }^{22}$. At the same time, the well known document of Henry I the Bearded for the Mogiła monastery, which refers to the regulations for the village of Prandocin introduced by the duke during the crusade ("cum in Prussiam ad expeditionem euntes fuisemus"), dates those regulations to 1235 ("Actum prope Quedinam in stationibus, anno ab incarnatione domini MCCXXXV") ${ }^{23}$, which allows us to date the crusade to the turn of 1234 and 1235 at the earliest ${ }^{24}$.

On the other hand, the validity of the record about Chełmno Law included in the document of Vladislaus Odonic of 1233 is considerably compromised by the uncertain authenticity of the document ${ }^{25}$. Although Karol Maleczyński, expert in

${ }^{20}$ Max Perlbach, [rev. Preussisches Urkundenbuch. Politische Abteilung, Bd. 1], Göttingische Gelehrte Anzeigen, 1884, Bd. 1, p. 111; the German scholar revised his stand point (see: idem, Preussische Regesten bis zum Ausgange des dreizehnten Jahrhunderts, Königsberg 1876, no. 126); it must be noted that before Perlbach did it, Johannes Voigt also had supported the option of dating the Chełmno privilege in 1232; later he seems to have doubted the legitimacy of his decision; see: M. ToEPPEN, Geschichte, p. 279 f.

${ }^{21}$ M. Perlbach, [rev. Preussisches Urkundenbuch. Politische Abteilung, Bd. 1], p. 111; see also: idem, Bericht über eine für das Pommerellische Urkundenbuch unternommene Reise nach Polen, Zeitschrift des Westpreussischen Geschichtsvereins, H. 1: 1880, p. 81; see the document in: Kodeks dyplomatyczny Wielkopolski, vol. 1, [ed. Ignacy ZAKrzewski], Poznań 1877 (further: KDW I), no. 149.

${ }^{22}$ Petrus de Dusburgk, Chronica Terrae Prussiae, ed. Jarosław WEnta, Sławomir Wyszomirski (Monumenta Poloniae Historica, Nova series, vol. 13), Kraków 2007 (further: Petrus de Dusburgk, Chronica Terrae Prussiae), p. III, cap. 10, 11, p. 57 f.

${ }^{23}$ Schlesisches Urkundenbuch, Bd. 2: 1231-1250, bearb. v. Winfried IRGANG, hrsg. v. Heinrich Appelt, Josef Joachim MenzeL, Wien-Köln-Graz 1977, no. 106.

${ }^{24}$ For a more extended justification of the dating see: Mikołaj GŁADYsz, Zapomniani krzyżowcy. Polska wobec ruchu krucjatowego w XII-XIII wieku, Warszawa 2002, p. $227 \mathrm{ff}$; idem, The Forgotten Crusaders. Poland and the Crusader Movement in the Twelfth and Thirteenth Centuries, Leiden-Boston 2012 , p. $239 \mathrm{ff}$.

${ }^{25}$ Teodor Tyc, Początki kolonizacji wiejskiej na prawie niemieckim w Wielkopolsce (1200-1333), Poznań 1924, p. 37, doubted the authenticity of the document, but failed to give reasons for his opinion; recently the authenticity has been questioned by Józef Piotr ŚLIwIŃsKI, Opactwo cystersów w Łeknie. Zarys dziejów o podstawach majątkowych od połowy XII do końca XIV wieku, Olsztyn 2013, 
the documents of Vladislaus Odonic, acknowledged the document to be genuine, he discerned quite a few peculiarities which distinguished the discussed text from other documents associated with Vladislaus Odonic. One of the peculiarities is the titulature, not used in other documents by Odonic ("dux Gneznensis"), nor in any other contemporary documents. Other peculiarities include the fact that the document was written on a piece of parchment which had been used before and that the seal had been attached prior to writing the text ${ }^{26}$. Maleczyński interpreted the latter circumstance as the evidence that the recipient of the document - the monastery in Łekno - received the document in blanco and drafted it themselves. Nevertheless, even this suggestion did not undermine Maleczyński’s belief that the document was not a fake as it was similar to several other documents issued by Vladislaus Odonic and Vladislaus III Spindleshanks for the monastery in Łekno ${ }^{27}$. As such a similarity could be easily explained in the case of a counterfeit, it should be considered a fake owing to the various peculiarities mentioned above. Moreover, the bad grammar and awkward style are additional arguments for the view that the document is not authentic ${ }^{28}$.

In this situation, the fact (underlined by Perlbach and confirmed by Maleczyński) that the remark about Chełmno Law was written in the same handwriting and with the same ink as the rest of the text (the remark is not an integral part of the text, but an annotation at the end of it), cannot guarantee that the document was drafted as early as $1233^{29}$.

So far no argument has been found which could tip the balance for the benefit of December 1232 as a more probable date of issuing the Chełmno privilege than December 1233. The question is whether we can announce the return to the status quo ante and recognise the latter option as correct. The answer is we cannot since some circumstances, hitherto unnoticed, would definitely support the dating of the Chełmno privilege to 28 December 1232.

Some are revealed by the document of the Magdeburg burgrave Burchard von Querfurt of 1233, in which Burchard confirmed the conditions of the settlement concluded with the abbot of the monastery of St. George in Naumburg about the advocation of some hides of land in the villages of Helfta and Faulensee ${ }^{30}$. The

p. $96 \mathrm{ff}$, who explained that the document included an obsolete record about Chelmno Law; the original of the document has survived and is preserved in the Jagiellonian Library under the entry number BJ Rkp. Dypl. 1.

${ }^{26}$ Karol MALECZYŃski, Studya nad dyplomami i kancelaryą Odonica i Laskonogiego (1202-1239), Lwów 1928, pp. $145 \mathrm{ff}, 176 \mathrm{f}$.

${ }^{27}$ See: ibid., p. 109 ff; it concerns the following documents: KDW I, no. 69, 79, 82, 87, 130, 131; Maleczyński considered the documents along with the diploma analyzed here to be "the work of one dictator of the [Łekno - M.D.] monastery" (K. MALECZYŃsKI, op.cit., p. 111).

${ }^{28}$ See: KDW I, no. 149.

${ }^{29}$ See: M. Perlbach, Bericht, p. 81; see also: K. Maleczyński, op.cit., p. 117 and table VIII, along with the digital photo of the original in the Jagiellonian Digital Library.

${ }^{30}$ Urkundenbuch des Hochstifts Naumburg, Teil 2: (1207-1304), hrsg. v. Hans Kurt Schulze, Köln-Weimar-Wien 2000 (further: UB des Hochstifts Naumburg II), no. 119. 
document bears only the year of its preparation, which is why not much significance has been attached to it as it has been thought not to provide any essential data for specifying the itinerary of Burchard von Querfurt ${ }^{31}$. However, despite the lack of the information about the month and the day of its issue, we may specify the chronology of its creation owing to the reference to the upcoming feast of the Assumption of Virgin Mary ("a festo assumptionis beate Mariae virginis nunc proximo"), which allows us to date the document in the summer of 1233. In this way, we acquire an important piece of information about Burchard's itinerary, which is fundamental to establishing the correct date of issuing the Chełmno privilege and which indicates the terminus ante quem or post quem of the crusade of the Magdeburg burgrave to Prussia.

From the perspective of the discussed problem, two factors are significant the fact that the Magdeburg burgrave stayed in Schraplau in the summer of 1233, where Burchard issued the discussed document, and the content of the settlement included in the document. The settlement stipulated that the Magdeburg burgrave would lease 8 hides of his land in Bornstedt to three knights mentioned in the document. In return for this, the above mentioned knights were to pay the abbot of St. George's monastery sixty marks of silver within one year from the upcoming feast of the Assumption of Mary. The sum of money constituted the compensation for the advocation of the hides of land in Helfta and Faulense, which was the cause of the conflict between the abbot and the Magdeburg burgrave. The three knights were to take over the previously mentioned eight hides in Bormstedt as a fief. However, if Burchard von Querfurt within a year from the upcoming feast of St. James had withdrawn from the advocation in Helfta and Faulensee or paid the abbot of St. George's monastery sixty marks of silver, he would have regained his eight hides of land in Bornstedt ${ }^{32}$.

As it seems, the stipulations of the settlement allow the conclusion that in the middle of 1233 Burchard von Querfurt did not intend to go on a crusade to Prussia if within the subsequent twelve months he planned to settle the property conflict described above and which he felt so strongly about. It should be underlined that another witness of the Chełmno privilege - Bartholomäus von Liebenau - was placed in a similar position by the settlement. He was one of the three knights who

${ }^{31}$ W. Cohn, op.cit., p. 394 f; E. MAschKe, op.cit., p. 149; M. LöWEner, Die Einrichtung, p. 63.

32 " [...] Nos itaque predicto domino nostro abbati et ecclesie sue sufficienter cavere volentes porreximus honorabilibus viris Rudolfo pincerne de Vergela et Bartholomeo de Lievenowe octo mansos in Bernstede sitos necnon et domino Henrico Crumpe, ut ipsi proinde dent iam dicto domino nostro abbati et ecclesie sue a festo assumptionis beate Marie virginis nunc proximo usque ad annum LX marcas puri argenti, et hii octo mansi erunt tunc feodum ipsorum pro pecunia iam predicta. Nobis etiam licebit ab huius feudi obligatione iam dictos absolvere mansos hac conditione, quod, si nos a festo beati Iacobi proximo usque ad annum advocatiam supradictorum mansorum Helpedhe et Vulense sitorum liberam fecerimus totaliter usque ad manum domini nostri episcopi Nuwenburgensis vel dederimus infra eundem terminum sepe dicto domino et ecclesie sue LX ${ }^{\mathrm{a}}$ marcas puri argenti, sepedicti octo mansi ad nos redibunt ab omni feudi obligatione liberi sicut ante. [...]" [underlined - M.D.]. 
were to lease Burchard's hides in Bornstedt and to pay the abbot of St. George's monastery sixty marks ${ }^{33}$.

The above observations do not constitute sufficient grounds to exclude the possibility of Burchard von Querfurt and Bartholomäus von Liebenau's participation in a crusade to Prussia in the second half of 1233 , and the possibility of their stay in Chełmno on 28 December 1233. Still, they make those two possibilities much less probable. Moreover, it must be noted that as early as 24 January 1234 - merely half a year after the settlement in Schraplau - Burchard von Querfurt appears in Thuringia ${ }^{34}$, which means that his potential stay in the crusade in Prussia after the settlement in Schraplau might have only lasted a few months, and not a year, as wrote Peter of Dusburg ${ }^{35}$. In the period prior to the settlement in Schraplau - the middle of 1233 - Burchard's itinerary does not exclude the possibility of his taking part in a one-year-long crusade, for he appears for the last time on 7 September 1231, when he witnessed a settlement between the archbishop of Magdeburg and the bishop of Naumburg ${ }^{36}$. To be exact, we must add that the conditions of this settlement obliged Burchard - as one of its guarantors - to remain in Saxony until it had been confirmed by the Magdeburg chapter, which took place on 4 June 1232. This is the date which indicates the actual terminus post quem of the potential crusade of Burchard to Prussia ${ }^{37}$. It must be underlined that the impossibility of according Johann von Pach's itinerary in the years 1232-1233 with the information from Peter of Dusburg about a year-long crusade of the Magdeburg burgrave does

${ }^{33}$ About him see: K. ZielińsKA-MelKowsKa, op.cit., p. 57 f, fn. 21; here let us notice that among the witnesses of the analyzed document of Burchard von Quefurt we encounter Otto von Buch, who was also in the witness list of the Chełmno privilege; see: K. ZielińsKA-MELKowsKA, op.cit., p. 58, fn. 24.

${ }^{34}$ Urkundenbuch der Erfurter Stifter und Klöster, Teil 1: (706-1330), bearb. v. Alfred OvERMANN, Magdeburg 1926, no. 238; the document does not bear any information about the place of its being issued; it lists Burchard accompanied by the landgrave of Thuringia Heinrich.

${ }^{35}$ Petrus de Dusburgk, Chronica Terrae Prussiae, p. III, cap. 9, p. 57: “[...] Sed dum vir ille nobilis et miles strenuus in armis de Saxonia burgrabius de Megdeburgk dictus cum parva manu multa stipatus milicia et armigeris veniret ad castrum Colmen, intra annum, quo ibidem mansit, ivit cum magistro et fratribus et castrum Insulae Sanctae Mariae praedictum transtulit de insula Quidini ad locum, ubi nunc est situm, in territorio Pomesaniae dicto Risen mutantes locum et non nomen. [...]" [underlined - M.D.]; let us note here that the relatively small time difference between 28 Dec 1233 and 24 Jan 1234, when Burchard von Quefurt was staying in his homeland, cannot constitute an argument in the discussion about the dating of the Chełmno privilege since it was possible to cover the distance from Chełmno Land to Thuringia in this period of time; there are no doubts about if we consider the findings about the time aspect of knightly peregrinations to Prussia obtained by Werner Paravicini, Die Preussenreisen des europäischen Adels, Teil 1, Sigmaringen 1989, p. 257 ff.

${ }^{36}$ UB des Hochstifts Naumburg II, no. 111.

${ }^{37}$ Ibid., no. 114; the document issued by the emperor Frederic in April 1232 in Aquileia, in which the emperor confirmed the privilege granted by the Magdeburg burgrave to the monastery of St. John in Berge near Magdeburg, does not play a significant role in establishing Burchard's itinerary. This document is only the renewed copy of the privilege granted by Burchard in the previous year and there is nothing in its content that would suggest the presence of the Magdeburg burgrave in the entourage of Frederic II; see: Urkundenbuch des Klosters Berge bei Magdeburg, bearb. v. Hugo Holstein, Halle 1879, no. 87, see also: ibid., no. 85. 
not undermine the significance of the above observations. Contrary to Löwener's assumptions, nothing makes us assume that the knight stayed in Prussia as a member of the crusade regiment of Burchard von Querfurt ${ }^{38}$.

Let us note here that apart from the previously mentioned reasons, another argument supporting the view that the Chełmno privilege should be dated to $28 \mathrm{De}$ cember 1232 is the analysis of the source material in terms of the various styles of beginning a new year used in the Teutonic Order state. The conclusions of the analysis favour the Nativity style, which was most frequently used in the epoch in the German lands as the manner of defining the beginning of the year ${ }^{39}$. The style referring to the celebrations of the Circumcision of Jesus did not appear in sources until the beginning of the $14^{\text {th }}$ century. The Annunciation style may be excluded completely in the case of the Chełmno privilege, while the style a nativitate is confirmed to have been used in Prussia in the $13^{\text {th }}$ century in at least two documents.

The first document was issued by the bishop of Ermland - who was also a Teutonic Order clergyman - Anselm. He confirmed the division of the territory of the Ermland bishopric into an area for the bishop and one for the Order, which happened "in Castro de Culmen Anno domini $\mathrm{M}^{\mathrm{mo}} \mathrm{CC} .{ }^{\circ}$ L. quinto. VI. Kalendas Januarii" ${ }^{40}$. The document was issued according to the style a nativitate, the evidence of which is the fact that the settlement certified by the bishop Anselm was confirmed on 10 March 1255 by Pope Alexander IV ${ }^{41}$, which makes it clear that the date of Bishop Anselm's document should be read according to the Nativity style and dated to 27 December 1254 as suggested by the publisher Carl Peter Woelky ${ }^{42}$.

The second example is the regestum of the document of the provincial master of Prussia Mangold issued in Chełmno "1283. Pridie Kalendas Januarii"43. Mangold left Prussia at the beginning of 1283 and soon afterwards he died, which means that the document should be dated according to the Nativity style to 31 December $1282^{44}$.

${ }^{38}$ A similar assumption was also made by Ch. Krollmann, Die Herkunft der deutschen Ansiedler in Preussen, Zeitschrift des Westpreussischen Geschichtsvereins, t. 54: 191, pp. 10, 12, and Jan Powierski, Prusowie, Mazowsze i sprowadzenie Krzyżaków do Polski, vol. 1, Malbork 1996, p. 24.

${ }^{39}$ About the prevalence of the Nativity style in Germany see in particular: Hermann GroteFEND, Zeitrechnung des deutschen Mittelalters und der Neuzeit, Bd. 1, Hannover 1891, p. 205 f.

${ }^{40}$ Codex Diplomaticus Warmiensis oder Regesten und Urkunden zur Geschichte Ermlands, hrsg. v. Carl Peter Woelky, Bd. 1, Mainz 1860 (further: CDW I), no. 31; comp. W. CoHn, op.cit., p. 391, where, owing to the bishop's provenance of the charter, the German scholar ignored its importance having forgotten that the bishop Anselm had belonged to the Teutonic Order.

${ }^{41}$ CDW I, no. 33.

${ }^{42}$ In the same way the publisher read the date of another document of the bishop Anselm (CDW I, no. 47: 29 December 1263), but in this case the use of the Nativity style is not so obvious; however, the itinerary of the bishop Anselm supports this view; see: M. DornA, Bracia, p. 329; idem, Die Brüder, p. 362.

${ }^{43}$ Preussisches Urkundenbuch, Bd. 1, 2. Hälfte, bearb. v. August Seraphim, Königsberg 1909 (further: PrUB I/2), no. 411; comp. W. CoHN, op.cit., p. 392, who regarded this document as invalid as it was not complete.

${ }^{44}$ The publisher August Seraphim acted in this way; about Mangold see: M. DornA, Bracia, p. 285; idem, Die Brüder, p. $311 \mathrm{f}$; let us note here that according to the Nativity style R. Philippi 
As far as the Circumcision style is concerned, the first proven example of its use by the Prussian Teutonic Knights are two documents of the provincial master Konrad Sack dated "anno domini $\mathrm{M}^{\circ} \mathrm{CCC}^{\circ} \mathrm{II}^{\circ}$ in die Sanctorum innocentum" (28 December) and "anno domini $\mathrm{M}^{\circ}$ CCC secundo Silvestri pape" (31 December), undoubtedly issued in December 1302, because in the previous year Helwig von Goldbach had been the provincial master ${ }^{45}$.

Willy Cohn drew attention to those examples. Following Max Toeppen, he indicated two $13^{\text {th }}$ century documents, which were to confirm the use of the style a circumcisione by the Teutonic Knights ${ }^{46}$. The first document issued by the provincial master Heinrich von Weida concerned the conditions of the foundation of a town in Samland by inhabitants of Lübeck and bore the dating formula: "Anno gracie MCCXLII. pridie Kal. Januarii, indictione XV", which Max Toeppen was inclined to date to 1242 owing to the number of the indiction ${ }^{47}$. The second example was a document issued by the archbishop of Riga John, dated "anno domini $\mathrm{M}^{\circ} \mathrm{CC}^{\circ} \mathrm{LXXXVI}$ pridie Kalendas Januarii". For Toeppen and Cohn, what held the key significance in this document was the fact that it listed the Pomesanian bishop Albert as dead, while in January 1286 he had been mentioned in the sources as a living person ${ }^{48}$.

Nevertheless, neither of the examples proposed by Toeppen and Cohn may be regarded as reliable, since in the case of the first document the indiction XV fell in 1242 , but this does not exclude the dating of Heinrich von Weida's document to 31 December 1241 (which implies using the Nativity style), if, according to the Roman indiction employed at that time by the Teutonic Order, it could be counted both from 1 January 1242 and 25 December $1241^{49}$. The value of the evidence pro-

and C.P. Woelky read the date of the agreement between Casimir of Kuyavia and the grand master Poppo von Osternohe concerning the division of Land Löbau, concluded in Inowrocław „Anno ab incarnacione dom. MCC Quinquagesimo quinto" (PrUB I/1, no. 303; Urkundenbuch des Bisthums Culm, Teil 1, bearb. v. Carl Peter Woelky, Danzig 1885, no. 36); the possibility that the agreement was drafted by the Kuyavian chancery makes this example useless for our speculations. Another issue is a lack of clear-cut evidence that the Nativity style was used in this document; about the dating of the document see: Jadwiga KarwasińsKa, Sąiedztwo kujawsko-krzyżackie 1235-1343 (Rozprawy Historyczne Towarzystwa Naukowego Warszawskiego, vol. 7), Warszawa 1927-1929, p. 43, fn. 1; comp. M. Perlbach, Preussische Regesten, no. 487, 488.

${ }^{45}$ W. CoHN, op.cit., p. 392 f.; PrUB I/2, no. 781, 782; despite the above mentioned circumstances the publisher A. Seraphim hesitated until the last moment which style he should use to read the documents, the clear evidence of which is the fact that he placed these documents among other documents of 1302, but with the date of 1301; comp. W. CoHN, op.cit., p. 393, fn. 1.

${ }^{46}$ See: M. Toeppen, Geschichte, p. 279.

${ }^{47} \operatorname{PrUB} \mathrm{I} / 1$, no. 140 .

${ }^{48} \operatorname{PrUB} \mathrm{I} / 2$, no. 498.

${ }^{49} \mathrm{R}$. Philippi was fully conscious of this ambiguity; he published the document with the date 31 December 1242, but he was not certain to act rightly; see: PrUB I/1, no. 140, p. 105, fn. 2 - the publisher's remarks; see also: Johann Friedrich Böhmer, Regesta Imperii V. Die Regesten des Kaiserreichs unter Philipp, Otto IV, Friedrich II, Heinrich (VII), Conrad IV, Heinrich Raspe, Wilhelm und Richard 1198-1272, Innsbruck 1901, no. 11373, where our document was published with the date 31 December 1241; the evidence of employing the Roman indiction in this period by the Teutonic Knights is provided by the document of the vice-provincial master Berlewin von Freiberg of 
posed in the second document by M. Toeppen is undermined by its Livonian origin and the fact that the Riga archbishop's document was not dated in the Nativity style does not mean that it employed the Circumcision style. As Augustus Engelmann proved once, it was dated according to the Annunciation style employed in Livonia in the $13^{\text {th }}$ century ${ }^{50}$.

As far as the Annunciation style is concerned, it may be excluded completely from the research on the dating of the Chelmno privilege if evidence exists that the co-drafter of the privilege, the provincial master Herman Balk, never used this style while dating his documents ${ }^{51}$.

Jan Powierski tried to read one of Balk's documents - the privilege of Hermann Balk for the Dominicans in Elbing dated "anno gracie M. CC. XXXVIII. Idus Januarii indiccione XI" - according to the Annunciation style believing that it would suit the itinerary of Hermann Balk better ${ }^{52}$. However, the date 13 January 1239 - when read in the Annunciation style - does not correspond to the indiction number given in the formula. On the other hand, the alternative date - 13 January 1238 - is compatible with this number.

The privilege of Hermann Balk for the knight Ditrich von Dypenau issued "anno gracie MCCXXXVI. IV. Kalendas februarii indiccione IX" follows the same pattern ${ }^{53}$. If we read the dating formula according to the Annunciation style, we will encounter a clash between the date obtained in this way - 29 January 1237 - and the indiction number. This problem disappears if we assume that this document was dated according to another style; in this case it would have been issued on 29 January 1236.

1 October 1239 (indiction XII) and the document of the provincial master Heinrich von Weida of 26 November 1242 (indiction XV); see: Urkundenbuch zur Geschichte des vormaligen Bisthums Pomesanien, H. 1, hrsg. v. Hermann Cramer (Zeitschrift des Historischen Vereins für den Reg.-Bezirk Marienwerder, H. 15: 1885), Marienwerder 1885 (further: UB Pomesanien), no. 2, 3.

${ }^{50}$ August Engelmann, Chronologische Forschungen auf dem Gebiete der russischen und livländischen Geschichte des 13. und 14. Jahrhunderts, Mitteilungen aus dem Gebiete der Geschichte Liv-, Est- und Kurlands, Bd. 9: 1860, p. $431 \mathrm{f}$.

${ }^{51}$ The opinion that the Annunciation style had been used while dating the Chełmno privilege was first put forward by R. PHILIPPI, PrUB I/1, nr 105, p. 77, fn. 1 - the publisher's notes; see also: T. JAsINsKi, Pierwsze lokacje, p. 39; K. ZielińsKa-MelkowsKa, op.cit., p. 23, fn. 2; R. Philippi based his belief about the Annunciation style being used in the dating of the Chełmno privilege on the findings of the research done by A. Engelmann, which prove the dominant role of this style in Livonia in that period. The publisher of Preussisches Urkundenbuch glozed over Engelmann's findings that apart from the Annunciation style sometimes the Nativity style was employed in Livonia at that time. It was certainly the latter style that was used to date the agreement between Hermann Balk and the bishop of Ösel about the division of the territory of Wieck of 28 February 1238; see: A. Engelmann, op.cit., p. $439 \mathrm{ff}$.

${ }^{52}$ CDW I, no. 1; Jan Powierski, Początek walk Krzyżaków o panowanie nad Zalewem Wiślanym i założenie Elblaga, [in]: idem, Prussica. Artykuly wybrane $z$ lat 1965-1995, vol. 2, Malbork 2005, p. 527 ff; comp. M. Dorna, Bracia, p. 223 f; idem, Die Brüder, p. 244, where I supported J. Powierski’s argumentation without having examined thoroughly the details concerning the dating of the discussed document issued by Hermann Balk.

${ }^{53}$ UB Pomesanien, no. 1. 
To find the final argument that would tip the scales towards the date of 28 December 1232 as the correct date for the foundation privilege for Chełmno and Torun, we must confront the arguments by which the choice of the other dating option was justified.

The key role here is played by a fragment of the chronicle of Peter of Dusburg devoted to the establishment of Marienwerder and the Prussian crusade of Burchard von Querfurt, in which the passage concerning the crusade of the Magdeburg burgrave was placed immediately after the information about the erection of the first Marienwerder castle in 1233, which was to mean that Burchard did not arrive in Prussia until $1233^{54}$

In the context of the previously mentioned date of Marienwerder's founding provided by Peter of Dusburg and the Prussian annals, another significant argument for the date of 28 December 1233 was the presence of "Lodewicus in Quedin provisor" among the witnesses of the Chełmno privilege ${ }^{55}$.

Recently, Dariusz Sikorski has added another argument for the dating of the Chełmno privilege in December 1233. According to him, Burchard von Querfurt could not have participated in the crusade in 1232 if we have no evidence for the crusaders' activity in Prussia in that period of time ${ }^{56}$.

In the case of the first two arguments, the fundamental question is the date of establishing the castle Marienwerder in Quidin Holm (1233) as provided by Peter of Dusburg. Marc Löwener made an attempt to undermine this date indicating that Peter of Dusburg had erroneously connected the establishment of the Marienwerder castle with the date of founding the town of Marienwerder. However, Löwener's reasoning faces one significant obstacle; namely, Peter of Dusburg separated those two events in his chronicle, announcing the founding of the town of Marienwerder in the context of his account about the great crusade of Polish dukes. If, as suggested by Löwener, Peter of Dusburg had followed some of the annals which heralded the foundation of the town, not the Marienwerder castle in 1233 , he would have placed the latter date in the chapter devoted to the aforementioned crusade ${ }^{57}$.

Despite the reservations concerning the argumentation of the German author it must be stated that his reasoning was sound when he tried to prove that we should not be forced to treat the chronology of Marienwerder's origin presented by Peter of Dusburg as an ironclad argument for dating the Chełmno privilege in 1233.

This conclusion resulted from the analysis of the fragment of the chronicle of Peter of Dusburg, devoted to the erection of the first temporary fortifications in Chełmno Land by the Teutonic Knights - the "watchtower on the oak" which, ac-

${ }^{54}$ M. Toeppen, Chronicon, p. 57, fn. 3 - the publisher's remarks; W. Cohn, op.cit., p. 395; comp. R. Phlipphi, PrUB I/1, nr 105, p. 77, fn. 1 - the publisher's remarks.

${ }^{55}$ E. MaschKe, op.cit., p. $149 \mathrm{f}$.

${ }^{56}$ D. SiKorski, op.cit., p. 82 f, fn. 89.

${ }^{57}$ See: Petrus de Dusburgk, Chronica Terrae Prussiae, p. III, cap. 10, p. 57. 
cording to the Teutonic chronicler, took place in $1231^{58}$. As I have already proved, this account of Peter of Dusburg was created by mixing two records - the account of the first Teutonic Order regiment arriving in Chełmno Land (devoid of any precise data) and the annalistic note of the construction of the Torun castle in 1231. On these grounds, I made a conclusion that the date "1231" had been associated by Peter with the moment of the Teutonic Knights' entering Chełmno Land, but in fact it refers only to the year of the erection of the Torun castle. This, in turn, allowed me to question the legitimacy of dating the beginnings of the Teutonic Knights' presence in Chełmno Land to 1231 and I moved it back to at least 1229, the evidence of which is the content of one of the papal bullas of January $1230^{59}$.

As it seems, in the case of Peter's account concerning the construction of the Marienwerder castle that this may be an analogous situation. Peter of Dusburg must have acquired the knowledge from the annals, in which the date of setting up Marienwerder might correspond not to the date of founding the temporary small castle in Quidin Holm, but to the construction of the second Marienwerder castle relocated by the Teutonic Knights and the participants of the crusade of Burchrd von Quefurt ${ }^{60}$. In other words, having discovered the date of Marienwerder's foundation in the Prussian annals, Peter of Dusburg could have failed to associate it with the fact with which the tradition linked the year 1233.

Even if there were no premises allowing us to question the chronology of Marienwerder's origin as presented by Peter of Dusburg, still there would be no grounds to date the crusade of Burchard von Querfurt to 1233 if the chronicler himself did not provide the date of the crusade expressis verbis. He probably did not find any information about it in his sources. The order of Peter's narration is too weak a premise to use to define the chronology of the events definitively ${ }^{61}$.

Let us note that some details of Peter of Dusburg's account about the origins of Marienwerder speak against dating the Chełmno privilege to 1233. Of particular significance here is the information that before the relocation of the castle in Quidin Holm, the Teutonic Knights had given the original small castle the name of "Insula Sancte Marie" (Marienwerder) ${ }^{62}$. This information has never been recalled in the context of the discussion concerning the dating of the Chelmno privilege. In fact, it is of vital importance if the provisor Ludwig - one of the witnesses of the Chełmno privilege - was referred to as "in Quedin provisor", and not "provisor Insulae Sancte Marie". In the light of this fact, it may be stated that the Chełmno privilege must have been issued before the first Marienwerder castle in Quidin Holm was granted the name Marienweder and was moved to a new site which,

${ }^{58}$ Ibid., p. III, cap. 1, p. 49.

${ }^{59}$ See: Maciej DonNa, Dwa rzekome dokumenty donacyjne dla Krzyżaków datowane na rok 1230, [in:] Pielgrzymi, pogrobowcy, prebendarze, ed. Błażej ŚLıwıŃski (Studia z dziejów średniowiecza, no. 15), Malbork 2009, p. 74 n, fn. 16; idem, Die Brüder, p. 242, 247, fn. 4.

${ }^{60}$ See the quote in fn. 35.

${ }^{61}$ Comp. E. MaschKe, op.cit., p. 149.

${ }^{62}$ Petrus de Dusburgk, Chronica Terrae Prussiae, p. III, cap. 9, p. 57. 
in turn, leads us to date the privilege to 28 December 1232 if on 28 December 1233 the castle had already been relocated jointly by the Teutonic Knights and the crusade regiment of Burchard von Quefurt. The exact date of the relocation is unknown, but in this case it is sufficient to establish that it could not have occurred after 28 December 1233 if on 24 January 1234 Burchard von Querfurt was staying in Thuringia, as is proved by the sources ${ }^{63}$.

The above mentioned reasoning might be contradicted by the argument that after changing the name of Quidin into Marienweder, the Teutonic Knights might have used both names for some time. It would have been a sensible argument if the name of the "Small Quidin" castle ("parvum Quidin") granted in 1236 by Hermann Balk to Dietrich von Dypenau implies the existence of a "big" Quidin ${ }^{64}$. However, if we take into account the fact that even in the mentioned document of Hermann Balk this "big" Quidin is referred to as "Insula Sancte Marie" (Marienweder) and that the Teutonic Knights consistently used the latter term, the use of the name "Quedin" in the Chełmno privilege is significant ${ }^{65}$. In other words, undoubtedly the title "in Quedin provisor" does not give us any grounds for questioning the possibility of the Chełmno privilege being issued on 28 December 1232 . What is more, it actually speaks in favour of it.

The last issue which should be considered is the problem of evidence for the presence of the Teutonic crusaders in Prussia as early as 1232. In fact, their presence is quite easy to prove. Suffice to say, the Teutonic crusaders must have been heading for Prussia at the turn of 1231 and 1232, when the Pope Gregory IX in the bull of 9 February 1232 appealed to the bishop of Vratislavia that the crusaders should be given help and that everybody who prevented them from reaching their final destination should be excommunicated ${ }^{66}$. The chronicle of Peter of Dusburg

${ }^{63} \mathrm{~J}$. Powierski also dated this removal in the period prior of 28 December 1233 (idem, Prusowie, p. 24); however, he did not notice the significance of his observations for the question of the dating of the Chełmno privilege.

${ }^{64}$ Comp. Waldemar Heym, Castrum parvum Quidin. Die älteste Burg des Deutschen Ritterordens in Pomesanien, Zeitschrift des Westpreussischen Geschichtsvereins, H. 70: 1930, p. 61; Hubert GóRNowicz, Toponimia Powiśla Gdańskiego, Gdańsk 1980, p. 85.

${ }^{65}$ UB Pomesanien, no. 1; an exception to the rule is the document of the bishop of Ermland, Anselm, of 29 December 1263 (CDW I, no. 47), in which the bishop of Pomesanien was referred to as "Quidinensis Episcopus". Yet, this fact does not undermine the above mentioned conclusions as the title used in Anselm's text resulted from the complaint made by the bishop of Wladislavia and the Wladislavia chapter about the Pomesanian bishop; the bishop of Ermland addresses this complaint in a given place in his document. It is known that among the Polish neighbours of the Teutonic Order state the name of Quidin was heavily associated with Marienwerder as moved to another place; see: H. Górnowicz, op.cit., p. 85 f.

${ }^{66}$ Tomasz JAsIŃski, Trzy nie znane oryginalne bulle Grzegorza IX dotyczace misji pruskiej z lat 1232-1234, ZH, vol. 53: 1988, no. 3-4, p. 65: “[...] Hinc est, quod discretionem vestram rogandam duximus et monendam, per apostolica vobis scripta mandantes, quatinus illis, qui amore fidei et devotionis fervore succensi succurrere cupiunt populo christiano contra perfidiam Prutenorum, impendentes omnimodum auxilium et favorem, quoslibet, qui se ipsis temere opponunt, excommunicationis sententia percellatis, ut sic depressa malorum audacia bonorum virtus clarior eluescat. [...]”. 
also informs us about the crusaders' presence in Prussia before 1233; it reads that they contributed to the establishment of the Chelmno castle and town ${ }^{67}$. Let us add that the propaganda machinery of the Prussian crusade steered by the pope commenced in 1230 and it quickly covered the territory of the Magdeburg church province ${ }^{68}$. In view of the above mentioned facts there is no reason to reject the possibility that Burchard von Querfurt started the Prussian crusade as early as the second half of 1232 .

Finally, I would like to make a comment about the grand master Hermann von Salza and the question of his participation in the foundation privilege for Chełmno and Torun ${ }^{69}$. Actually, the itinerary of the grand master does not provide grounds to exclude his presence in Chełmno Land at the turn of 1232 and 1233 since between September 1232, when the grand master was staying in the south of Italy with the emperor, and the end of the first semester of 1233, when Hermann von Salza negotiated the conditions of the peace treaty in the Holy Land, there seems to have been enough time for him to travel to the Chełmno Land ${ }^{70}$. On the other hand, the fact that pope Gregory IX in July 1232 wrote a letter to the Teutonic grand master asking him to support the patriarch of Antiochia in the mediations in the Holy Land, should have stopped Hermann von Salza from leaving the Mediterranean region $^{71}$. Nevertheless, the scarcity of sources prevents us from resolving the issue. Thus, the question about the possible stay of the grand master in Chełmno on 28 December 1232 must remain unanswered.

To recapitulate, despite the fact that the arguments provided by Max Perlbach and later by Marc Löwener turned out to be irrelevant, it is their dating of the Chełmno privilege - 28 December 1232 - that is most probably correct. There are seven arguments supporting this option: (1) the content of the settlement in Schraplau signed in the middle of 1233, suggesting that Burchard von Querfurt and Bartholomäus von Liebenau did not have the intention of leaving their homeland for a longer time, (2) a gap in the itinerary of Burchard von Querfurt between the beginning of June 1232 and the summer months of 1233 , which could be the time of his one-year-long crusade in Prussia, (3) a lack of such a gap in the period after signing the settlement in Schraplau, (4) the sources proving that the Nativity style was used in the Teutonic Order state in the $13^{\text {th }}$ century, (5) a lack of evidence that the Circumcision style was used by the Teutonic Knights in Prussia in the $13^{\text {th }}$

${ }^{67}$ Petrus de Dusburgk, Chronica Terrae Prussiae, p. III, c. 8, p. 56.

${ }^{68}$ See: M. GŁadysz, Zapomniani krzyżowcy, p. 217 ff; idem, The Forgotten Crusaders, p. 227 ff.

${ }^{69}$ About the discussion concerning Hermann von Salza's participation in the foundation act of Chełmno and Toruń see: M. Dorna, Bracia, p. 231 ff; idem, Die Brüder, p. 251 ff; see also: K. MiliTZER, op.cit., p. $3 \mathrm{f}$.

${ }^{70}$ About Hermann von Salza's stay in the south of Italy in September 1232 see: M. Löwener, Die Einrichtung, p. 53, fn. 26.

${ }^{71}$ MGH. Epp. saec. XIII, no. 477; to be exact, the appeal was not directed exclusively to Hermann von Salza, but also to the grand master of the Hospitallers and to the grand master of the Templars along with other officials of the Kingdom of Jerusalem. 
century, (6) the existence of evidence which excludes using the Annunciation style by the co-drafter of the Chełmno privilege - the provincial master Hermann Balk, (7) the titulature of "Lodewicus in Quedin provisor", which does not correspond to the period after the original Quidin (Marienwerder) castle was relocated.

These are, as it seems, sufficient grounds to acknowledge that the foundation privilege for Chełmno and Torun should be dated to 28 December 1232. This is reinforced by the fact that the chronology of Marienwerder's origins, which was the main argument for the dating of 28 December 1233, does not provide grounds for a definite exclusion of the possibility of Burchard von Querfurt's crusade arriving in Prussia as early as the second half of 1232.

Received $25^{\text {th }}$ September 2015

Received in revised form $20^{\text {th }}$ December 2015

Accepted 27 $7^{\text {th }}$ December 2015

Dr hab. Maciej Dorna

Instytut Historii

Uniwersytet im. Adama Mickiewicza w Poznaniu

e-mail:maciej.dorna@interia.pl

O CZASIE WYSTAWIENIA PRZYWILEJU LOKACYJNEGO

CHEŁMNA I TORUNIA

\section{Streszczenie}

Słowa kluczowe: dyplomatyka, przywilej chełmiński, zakon krzyżacki, ziemia chełmińska

Tematem artykułu jest kwestia datacji przywileju lokacyjnego Chełmna i Torunia. Omówiono w nim dotychczasową dyskusję i starano się ocenić wartość sformułowanych w jej trakcie argumentów. Dużo miejsca autor poświęcił na analizę argumentacji niemieckiego badacza Marca Löwenera, który podjął próbę rewizji utrwalonego w nauce poglądu, że datą wystawienia przywileju lokacyjnego Chełmna i Torunia był 31 XII 1233 r. W opinii autora próba ta nie przyniosła przekonywających argumentów za datowaniem przywileju chełmińskiego na rok 1232, jednak mimo to autor również uznał ten wariant datacji za właściwy. Za słusznością tego wyboru przemawia zdaniem autora m.in. treść dokumentu, wystawionego przez burgrabiego magdeburskiego Burcharda z Kwerfurtu w Schraplau w $1233 \mathrm{r}$. W ten sam sposób autor zinterpretował również wyniki swoich badań nad stosowaniem w państwie zakonnym w Prusach różnych stylów rozpoczynania roku, świadczące o tym, że w XIII w. Krzyżacy posługiwali się stylem a nativitate. Poza tym za argument przemawiający za datowaniem przywileju chełmińskiego na 1232 r. autor uznał użyty 
w przywileju chełmińskim tytuł Ludwika prowizora kwidzyńskiego („Lodewicus in Quidinprovisor”), dowodząc, że w grudniu 1233 r. tytuł ten powinien mieć formę „provisor Insule Sancte Marie".

\section{ZUM ZEITPUNKT DER AUSSTELLUNG DES LOKATIONSPRIVILEGS VON KULM UND THORN}

\section{Zusammenfassung}

Schlüsselwörter: Diplomatik, Kulmer Handfeste, der Deutsche Orden, Kulmerland

Thema des vorliegenden Artikels ist die Datierung des Lokationsprivilegs von Kulm und Thorn. Der Autor bespricht in ihm die bisherige Diskussion und versucht das Gewicht der Argumente einzuschätzen, die in ihrem Verlauf geäußert worden sind. Breiten Raum widmet der Autor einer Analyse der Argumentation des deutschen Forschers Marc Löwener, der versucht hat die in der Wissenschaft etablierte Ansicht zu revidieren, wonach das Ausstellungsdatum des Lokationsprivilegs von Kulm und Thorn der 31. Dezember 1233 gewesen sei. Nach Ansicht des Autors hat dieser Versuch keine überzeugenden Argumente dafür erbracht, die Kulmer Handfeste auf das Jahr 1232 zu datieren, jedoch hält auch der Autor diese Datierungsvariante trotzdem für zutreffend. Für die Richtigkeit spricht nach Meinung des Autors u. a. der Inhalt einer Urkunde, die 1233 von dem Magdeburger Burggrafen Burkhard von Querfurt in Schraplau ausgestellt wurde. Auf die gleiche Weise interpretiert der Autor auch die Ergebnisse seiner Untersuchungen zur Verwendung von verschiedenen Stilen des Jahresbeginns im preußischen Ordensstaat. Diese Ergebnisse belegen, dass die Ritter des Deutschen Ordens sich im 13. Jahrhundert des Stils a nativitate bedienten. Außerdem bewertet der Autor den in der Kulmer Handfeste benutzten Titel von Ludwig, Provisor von Marienwerder („Lodewicus in Quidin provisor”), als Argument für die Datierung der Kulmer Handfeste auf 1232. Er zeigt, dass dieser Titel im Dezember 1233 die Form „provisor Insule Sancte Marie” gehabt haben müsste. 